\title{
A Time for More Booms and Fewer Busts? Unraveling Cereal-Rust Interactions
}

\author{
Scot Hulbert ${ }^{1,2}$ and Michael Pumphrey ${ }^{2}$ \\ ${ }^{1}$ Department of Plant Pathology and ${ }^{2}$ Department of Crop and Soil Sciences, Washington State University, Pullman 99164- \\ 6430 , U.S.A.
}

Submitted 30 September 2013. Accepted 18 December 2013.

\begin{abstract}
Recent advances in our understanding of the nature of resistance genes and rust fungus genomics are providing some insight into the basis of resistance and susceptibility to rust diseases in our cereal crops. Characterized rust resistance genes, for the most part, resemble other resistance genes that interact with effectors intracellularly, but some have unique features. Characterization of rust effectors is just beginning but genomic information and technical advances in rust functional genomics will accelerate their characterization. The ephemeral nature of resistance in past varieties has made the design of cultivars with durable resistance a major focus for geneticists and cereal breeders. This includes strategies for deploying race-specific resistance genes that prolong their effects and methods of predicting which will be difficult for the pathogen to defeat. Identification of resistance genes with race-nonspecific effects is another strategy where recent breakthroughs have been made. Routinely combining the numerous genes required for complex resistance, whether specific or nonspecific, in elite cultivars remains a primary constraint to realizing durable resistance in most programs.
\end{abstract}

The cereal rusts, caused by various Puccinia spp., are among the most agriculturally damaging groups of diseases historically and in modern times. Puccinia rusts attack most of our major cereal species, including wheat, maize, barley, and sorghum. Their ability to produce multiple cycles of asexual spores (urediniospores) in a single season, the vast numbers of spores produced, and their ability to travel long distances create a potential for destructive epidemics if the cereal varieties are susceptible and weather conditions favorable. With few effective cultural control methods, production of the large acreages of cereals needed to feed the world has required the development of resistant crop varieties along with fungicide applications if possible and affordable. Therefore, rust resistance is a major objective of most cereal variety breeding programs around the world. Breeding for resistance has, for the most part, been an effective way of controlling the disease and the efforts spent on breeding, rust monitoring, and other research has shown a good return on the investment globally (Pardey et al. 2013). Although resistance breeding has been mostly cost effective, it is costly, and regional failures are not uncommon. The best-known failure in contemporary times is the recent

Corresponding author: S. Hulbert; E-mail: scot_hulbert@wsu.edu

(C) 2014 The American Phytopathological Society lack of wheat varieties showing resistance to stem rust (Puccinia graminis f. sp. tritici) in Eastern Africa due to the emergence of highly virulent races. This helped stimulate investments in applied and more basic rust resistance research, including the Borlaug Global Rust Initiative and federal funding for wheat breeding and rust genome sequencing. Although less acknowledged, the global failure of stripe rust resistance in wheat over the past decade has caused tremendous losses in East Africa and across Asia, North America, and Australia.

Efforts spent on incorporating rust resistance into varieties interfere with progress in improving other important traits such as yield and resistance to other pathogens and abiotic stressors, as well as various quality traits for different end uses. Unlike most traits, rust resistance is a moving target that sometimes moves very quickly. Because rust fungi evolve rapidly, a cereal variety that is highly resistant one year may be susceptible the next. Rust susceptibility is typically a fatal flaw for small grain varieties; therefore, otherwise excellent cultivars must be replaced, leaving both breeders and farmers disappointed. At the same time, resistance must be as cheap and effective as chemical control, because the low cost of fungicides and high grain prices experienced by many farmers around the globe in recent years have altered perspectives on the importance of variety resistance.

General features of characterized rust resistance genes.

Cereal species typically carry many genes for resistance to the rust species that attack them. In addition, species such as wheat, which can be hybridized with a large number of closely related species, have access to many rust resistance $(R)$ genes. Over 150 wheat rust genes controlling resistance to leaf rust (P. triticina), stem rust ( $P$. graminis), or stripe (aka yellow) rust ( $P$. striiformis) have been given the corresponding $\mathrm{Lr}, \mathrm{Sr}$, or $\mathrm{Yr}$ gene designations (Lagudah 2011; McIntosh et al. 1995). Although the actual genes have been identified for only a sample of these, the trend emerging is that most of them belong to the most typical class of $R$ genes, the nucleotide-binding leucinerich repeat (NB-LRR) genes. Examples include the wheat leaf rust $R$ genes $\operatorname{Lrl}$ (Cloutier et al. 2007), LrlO (Feuillet et al. 2003), and Lr21 (Huang et al. 2003); the stem rust $R$ genes Sr33 and Sr35 (Periyannan et al. 2013; Saintenac et al. 2013); and the maize common rust $R p 1$ and $R p 3 R$ genes (Collins et al. 1999; Webb et al. 2002). Two separate NB-LRR proteins are required for the $\mathrm{LrlO}$ resistance function (Loutre et al. 2009) while additional proteins required for the other resistances have not yet been identified but very likely exist. The proteins encoded by NB-LRR genes generally interact directly or indirectly with effector proteins in the host cytoplasm. A 
cytoplasmic location would be expected if most rust genes function to recognize the presence of effector proteins secreted from rust haustorial cells. Work with the flax rust system has indicated that this is generally the case. The L, M, P, and $\mathrm{N}$ loci of flax are composed of NB-LRR loci (Anderson et al. 1997; Dodds et al. 2001a and b; Lawrence et al. 1995). Avirulence (Avr) genes from the flax rust fungus (Melampsora lini) have been identified that are recognized by proteins encoded by genes at the L, M, and P loci. Each of the Avr genes were expressed in rust haustoria and predicted to encode proteins that were secreted from the haustoria. Expression of both the resistance proteins and the corresponding Avr proteins in plant cell cytoplasm caused a hypersensitive reaction (HR) (Catanzariti et al. 2006; Dodds et al. 2004). The nature of the $R$ gene-Avr gene interactions has been best characterized for the $\mathrm{L}$ genes. $\mathrm{L}$ is a simple locus with an allelic series with different specificities. $L$ proteins from the $L 5, L 6$, and $L 7$ alleles were shown to interact directly with a family of effectors coded by pathogen genes at the AvrL567 locus. Individual AvrL567 proteins caused HR of variable intensity with one or more of the three $L$ alleles that interact with the family, in a pattern explaining the recognition specificities (Dodds et al. 2006). Interactions between the different $\mathrm{R}$ and corresponding Avr proteins varied in the strength in which they bound the effectors in yeast two-hybrid protein interaction assays, with only the stronger interactions corresponding to clear incompatible phenotypes in planta. Analysis of site-directed mutations and a series of chimeric L proteins indicated that the interactions involved multiple protein surfaces acting additively to determine the nature of the interaction with the effectors (Ravensdale et al. 2012). Sequence comparisons between the $\mathrm{L}$ alleles and the AvrL567 genes indicated that both genes evolved under diversifying selection, as would be expected for strong selection for host and pathogen proteins changing to recognize or avoid recognition while they coevolved. Evidence for diversifying selection has also been observed for most of the other NB-LRR rust $R$ genes where multiple alleles or family members have been compared. Whether they interact directly with fungal proteins or recognize their presence indirectly has generally not been determined.

The barley Rpg1 gene is used extensively in the Upper Midwest states of the United States and prairie provinces of Canada for resistance to the wheat stem rust fungus ( $P$. graminis $\mathrm{f} . \mathrm{sp}$. tritici). The resistance conferred by Rpgl is race specific but has provided resistance to a very broad spectrum of races. It has made a major contribution in protecting barley from wheat stem rust for most seasons over the last 60 years (Kleinhofs et al. 2009; Steffenson 1992). Rpgl codes for a serine/threonine protein kinase (S/TPK), another common class of resistance protein and one that is known to participate in at least some NB-LRR-mediated resistances. Probably the most striking feature of the Rpgl-mediated interaction with $P$. graminis f. sp. tritici is the rapidity in which the interaction starts. The RPG1 protein is phosphorylated after inoculation with avirulent $P$. graminis f. sp. tritici isolates but not virulent isolates and is subsequently degraded. Phosphorylation can be observed within $5 \mathrm{~min}$ after inoculation of the leaf surface (Nirmala et al. 2010). The observation that arginine-glycine-aspartic acid tripeptide blocked infection and RPG1 phosphorylation prompted the purification of protein complexes by RGD affinity chromatography from germinated spores of the avirulent isolate (Nirmala et al. 2011). This led to the identification of two proteins: an 818-amino-acid RGD binding protein with a fibronectin type III and a breast cancer type 1 susceptibility protein domain and a 744-amino-acid protein with a vacuolar protein sorting-associated protein 9 domain and a coupling of ubiquitin to endoplasmic reticulum degradation domain. When infiltrated into Rpgl barley leaves together, the proteins elicit
RPG1 phosphorylation and an HR. Transcript analysis of the two proteins indicated that they were expressed in germinated and ungerminated urediniospores as well as purified haustoria. The two proteins interacted with each other and with functional RPG1 protein in yeast two-hybrid assays. The early events in the Rpgl-mediated resistance demonstrate that some plant rust interactions start well before haustoria formation. Histological analysis of rust resistance in some wheat cultivars has indicated that one component of their resistance is "prehaustorial", with quantitatively fewer infections advancing to the stage of haustoria formation (Wesp-Guterres et al. 2013). It is not known whether this prehaustorial resistance results from active responses to early recognition such as the Rpgl-mediated reactions or if it results from other physiological aspects of these cultivars.

Some of the other barley rust $R$ genes have unusual but not completely unique features. The barley Rpg5 gene provides resistance to some strains of the rye stem rust pathogen, $P$. graminis f. sp. secalis. The Rpg5 protein codes for NB-LRR and S/TPK domains. It is unusual for both NB-LRR and S/TPK domains to occur in the same protein but this has also been observed in the protein encoded by the wheat $T s n 1$ gene, which confers susceptibility to fungal pathogens expressing the protein toxin ToxA (Faris et al. 2010). The domains in the two proteins are arranged differently with respect to the $\mathrm{N}$ and $\mathrm{C}$ termini, however, and they probably arose through separate gene fusion events. The barley rpg 4 gene is unusual in the number of gene products known to be required and the fact that they are all very tightly linked genetically. The rpg4 resistance is effective against many wheat stem rust races. Fine mapping and silencing analyses have indicated that Rpg5, an NB-LRR gene (HvRgal), and an actin depolymerizing factor (ADF) designated HvAdf3 (Wang et al. 2013), all contribute to resistance. An ADF gene has also been found to be required for the RPS5/PBS1-mediated resistance of Arabidopsis to Pseudomonas syringae strains with $A v r P p h B$ (Tian et al. 2009). Genetic analysis indicated that there was a fourth unidentified linked gene required for the rpg4 resistance which also mapped to the same genomic region. Another interesting feature of rpg 4 is that it segregates as though resistance is recessive, indicating that either two copies of one of the factors is required for noticeable levels of rust resistance or possibly that a gene in susceptible haplotypes (linked in trans) inhibits the resistance (Wang et al. 2013).

Two other wheat rust $R$ genes have unique structures for disease $R$ genes. The $L r 34$ gene codes for an ABC transporter (Krattinger et al. 2009). Lr34 provides partial resistance that is most apparent at the adult plant stage and is somewhat dependent on environmental conditions and genetic background (German and Kolmer 1992; Singh and Huerta-Espino 2003). Although its actual mechanism of action is not known, it provides resistance to multiple biotrophic pathogens, including stripe rust and powdery mildew (Krattinger et al. 2009; Lagudah 2011). The Yr36 gene codes for a protein with an S/TPK domain as well as a domain with homology to steroidogenic acute regulatory protein-related lipid transfer (START) domains ( $\mathrm{Fu}$ et al. 2009). Under high temperatures (25 to $35^{\circ} \mathrm{C}$ ), Yr36 confers resistance to all Puccinia striiformis isolates tested to date.

\section{Realizing durable resistance.}

The periodic losses due to the transient nature of rust resistance in cereal varieties has stimulated decades of discussion on why some cultivars remain resistant longer and how to select or identify this type of resistance. Factors that would affect how long the resistance in a cultivar remained effective would include the number of $R$ genes that were independently con- 
tributing to resistance as well as the resistance mechanism of the actual genes. Mechanistic factors include the nature of the pathogen components that interact with the resistance proteins or whether the $R$ gene has true nonspecific effects, such as a gene that controlled physiological aspects of the plant independent of the pathogen, such as the Lr34 gene (below). Good predictors of durability to date have been inconsistent and the only real measure has been the test of time. Certain durability trends have emerged, however. Cultivars with resistance that is controlled by several genes with small effects, typically mapped as quantitative trait loci (QTL), are often durable, as are those controlled by genes that function mainly in adult plants and not seedlings (Ayliffe et al. 2008; Lagudah 2011).

Clearly, genes with only small or adult plant effects should not be assumed to be race nonspecific. Some race-specific genes have relatively small effects on traits such as uredinia size. Spontaneous recombinants at the Rpl and Rp3 loci have been identified that have the same specificity and, presumably, the same function as the progenitor gene but provide weaker resistance (Sun et al. 2001; Webb et al. 2002). Pathogen adaptation to resistance controlled by multiple genes with small race-specific effects might be slower because selection for mutations to virulence on any one gene would be weaker. Pathogen adaptation to wheat lines with such multigenic resistance has been documented (Johnson 1978), indicating that components of the resistance were at least partly race specific. Careful QTL analysis of partial $R$ genes with multiple races have, in some cases, such as the barley leaf rust system (Qi et al. 1999), found both seedling and adult plant resistance QTL to be race specific. It is common for QTL with partial effects to not be detected consistently across environments, and very little is known about additive and epistatic interactions among rust resistance QTL (Singh et al. 2013; Yu et al. 2011). Environmental conditions, pathogen population structure, timing of epidemic development, and genetic background all seem to significantly influence the expression of partial resistance phenotypes. Thus, progress in characterizing genes underlying QTL has been slow because fine mapping is difficult and requires careful control of the environment and genetic background of the mapping family and detailed quantification of the resistance phenotypes. Race-specific adult plant resistance is very common in the wheat-stripe rust system (McIntosh et al. 1995; Parlevliet 1985; Sthapit et al. 2012) (X. Chen and E. Milus, personal communication), though publications are limited, presumably due to the low priority of mapping defeated race-specific $R$ genes and perhaps a bias toward promoting durability of resistance phenotypes expressed in the adult stages. The wheat leaf and stem rust pathosystems have comparatively less evidence of race-specific adult plant resistance but examples such as Lr12 demonstrate why care should be taken when characterizing new resistances (Singh and Bowden 2011).

\section{Utilizing race-specific resistance.}

Combining multiple effective $R$ genes into a single cultivar is probably the most frequently strategized approach for durable rust resistance. The advantage of assembling a pyramid of effective $R$ genes is diminished if the component $R$ genes are deployed separately because it provides sequential selection of rust populations to overcome the components. Preventing individual deployment of these genes can be problematic, especially when the durably resistant cultivar is used as a parent for further breeding efforts. One approach is to recombine effective alleles of tightly linked $\mathrm{R}$ genes together into a single haplotype. This has been done in maize, where many of the common rust $R$ genes map to a single complex locus designated $R p l$ (Hu et al. 1996). In other crops, such as wheat, the rust $R$ genes are more distributed through the genome and useful combinations of genes that are linked are more difficult to find. In addition, those that have been introduced from distantly related species sometimes recombine poorly in the introgressed region. Substantial investment has been made in reducing the size of alien translocations over the past several years. A few potential targets for linkage blocks have emerged over the past few years for wheat stem rust resistance, including genes newly introgressed from Aegilops tauschii that are reported to be in reasonably tight linkage with other genes effective against virulent East African races (Olson et al. 2013). Chromosome 2B of wheat harbors numerous stem rust $R$ genes, including $S r 39$, $\mathrm{Sr} 40, \mathrm{Sr} 28$, SrWeb, SrGabo56, and Sr47, and active efforts are aimed at determining linkage relationships and assembling linkage blocks when feasible (Pumphrey 2012). The eventual success of such efforts will likely be determined by whether or not the resulting recombinant chromosomes have favorable alleles for other traits, including yield, quality, and resistance to other pests and diseases. Another pyramiding idea increasing in popularity is to clone and assemble numerous effective genes in cassettes to be used via transformation, where the genes are re-introduced as a single locus. This concept is being discussed for specific and nonspecific $R$ genes or as combinations, because each strategy should benefit from accumulating several genes for durable or high-level resistance (Saintenac et al. 2013). This approach has the advantages of avoiding the linkage drag from multiple introduced chromosome segments and the resulting single locus is easier to manipulate in breeding. Cloning genes in wild Triticeae family species that have never been deployed in agriculture is being emphasized for $R$ genes to be used in cassettes. Genes from other species will not necessarily be inherently more durable but their use only in combinations and not deployed individually may achieve this result. Designed cassettes may overcome the limitations of linkage to poor alleles of genes controlling other traits under selection, and would simplify stewardship and deployment.

Recognition of highly conserved pathogen-associated molecular patterns (PAMPs) has been generally found to be performed by membrane-spanning proteins with extracellular receptors rather than intracellular proteins such as NB-LRR (Dodds and Rathjen 2010; Jones and Dangl 2006). None of the rust $R$ genes identified to date have properties of the characterized pattern recognition receptors (PRR) that detect PAMPs. This is probably because these more conserved functions are not typically variable in cereal species, not because PRR are not involved in rust resistance. If we borrow from what has been learned about how many phytopathogenic bacteria effectors function, it is likely that some rust effectors act to suppress responses elicited by PAMP recognition (Dodds and Rathjen 2010; Hogenhout et al. 2009). The function of the LysM effector of Cladosporium fulvum in suppressing chitin-mediated defenses supports this perception (de Jonge et al. 2010). The difference between what is considered a PAMP versus an effector is sometimes arbitrary (Thomma et al. 2011). Rust fungi may have PAMP-like molecules that are not yet apparent and effector-like proteins vary in their degree of conservation between the rusts. An example might be a molecule released during haustoria expansion and formation of the extrahaustorial matrix and could be recognized by an intracellular receptor. The $Y r 36$ gene is interesting in this regard because it codes for a protein with a START domain, which are often involved in lipid binding (Fu et al. 2009). Yr36 has shown partial resistance to all stripe rust isolates tested under the appropriate environmental conditions but its durability is still largely untested in the field because it has not been widely deployed.

$R$ genes that detect conserved effectors may provide more durable resistance, and the extent to which effectors are conserved between species can be easily tested for Puccinia spp. 
because genome sequences of three are currently available. Probably more important than conservation is the function of the effector, because it would affect how easily the pathogen components recognized are lost or altered to escape recognition. Pathogen effectors in general are not equal in their contribution to a pathogen's fitness or pathogenicity, and this has been proposed as a method of predicting $R$ gene durability (Ayliffe et al. 2008; Leach et al. 2001). Genomic analysis of rust pathogens have indicated that they carry large arsenals of effector-like proteins that are expressed during plant infection or specifically in haustoria and have motifs indicating that they are secreted (Duplessis 2011; Garnica 2013). Although the importance of any one effector likely depends on which others are present in a given isolates genome, methods to predict which ones represent essential processes in some strains may allow the prediction of $R$ gene or gene combinations that are potentially more durable. With the recent demonstration that rust genes expressed in haustoria can be silenced, methods are now available to examine which genes are essential to pathogenicity (Panwar et al. 2013a and b; Yin et al. 2011). The silencing assays can be performed by introducing RNA fragments of the fungal genes into cereal seedlings using viral or Agrobacterium vectors and can be performed much more easily than making stable transgenic plants. Prediction of $R$ gene durability requires that we know which $R$ gene in the cereal cultivars or potential donor species corresponds to each effector. These associations are just beginning to be made but rust gene silencing assays and other techniques being developed for delivering effectors into cereal species will speed this process (Upadhyaya et al. 2014; Yin and Hulbert 2011). Understanding the cellular targets of important effectors may also inform predictions for durability once these targets are identified. Effectors that are recognized by $R$ genes indirectly, through their modification of important cellular targets, may be more difficult to lose or alter to escape recognition because their function is more directly tied to their evolution. Modification of the host target has also

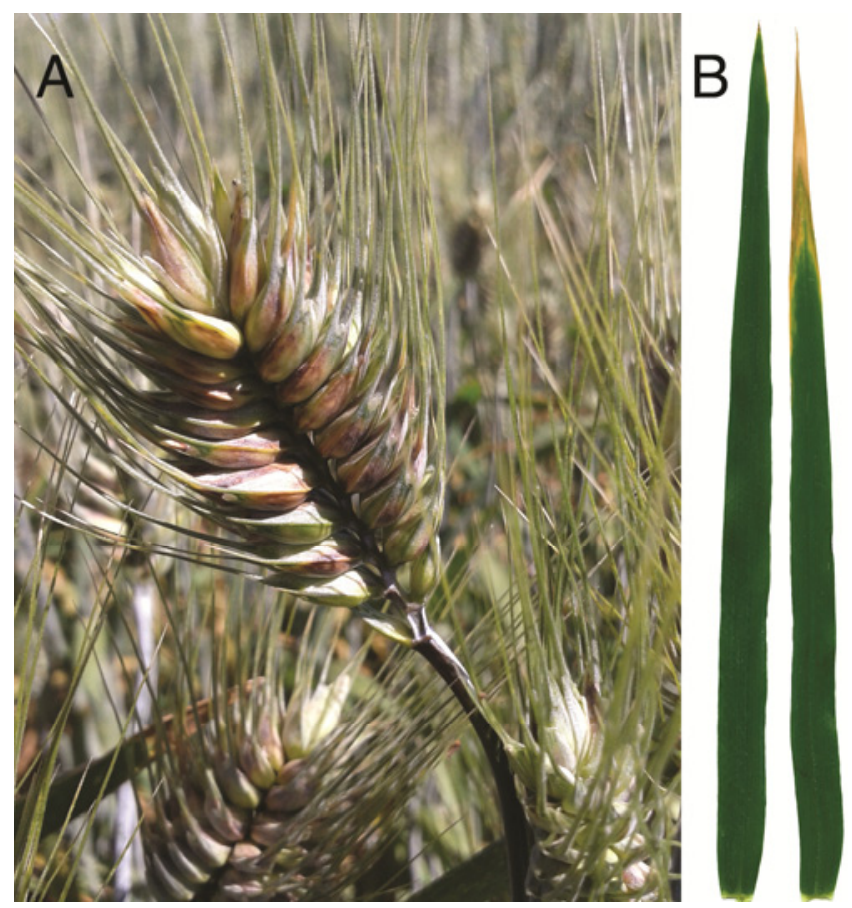

Fig. 1. Phenotypes associated with nonspecific wheat rust resistance genes. A, Pigmented glumes on a wheat spike from the pseudo black chaff phenotype associated with $\mathrm{Sr} 2$. B, Leaf tip necrosis associated with the Lr34 gene; flag leaf on left is from 'Thatcher' and the right is from an isoline carrying Lr34. been proposed as a possible method to engineer rust resistance (Ayliffe et al. 2008) by interfering with the virulence function of the effectors.

\section{Nonspecific resistance.}

A few $R$ genes are thought to confer resistance in a nonspecific manner, not through interactions with a specific effector. The best studied is the Lr34 gene of wheat (syn. Yr18/Sr57/ $P m 38 / S b 1 / B d v 1$ ). Thus, features of this gene have been considered when looking for other potentially durable genes. As mentioned above, Lr34 confers partial resistance, mainly in adult plants, and provides partial resistance to multiple pathogens, including stripe rust, stem rust, powdery mildew, spot blotch, and Barley yellow dwarf virus. In fact, Lr34 also confers resistance to barley leaf rust and powdery mildew in transgenic barley harboring a genomic copy of the wheat gene (Risk et al. 2013). The later feature is unusual because $R$ genes are generally effective against only a single rust species. Another unusual but not unique phenotypic feature of Lr34 is that it is associated with necrosis on the tips of adult leaves. Analysis of gene expression in the non-necrotic parts of these leaves found altered expression of multiple genes even in the absence of the pathogens (Hulbert et al. 2007). Many of the genes were those typically associated with abiotic stress responses, not typical defense response genes. In addition to $L r 34$, partial $R$ genes Lr67 (syn. Yr46/Sr55/Pm46) (Herrera-Foessel et al. 2011; Hiebert et al. 2010; Spielmeyer et al. 2013) and Lr46 (syn. Yr29/Sr58/Pm39) (Lillemo et al. 2013; Singh et al. 1998) confer resistance to multiple pathogens. Variable levels of necrosis on the tips of adult leaves are associated with each of these genes, even in the absence of pathogen challenge. Another multiple-pathogen partial rust resistance locus associated with a phenotype without rust infection is Sr2 (syn. Yr30/Lr27) (Mago et al. 2011), which confers a variable level of purpleblack pigment on glume, peduncle, and below-stem internode tissues (Kota et al. 2006). Numerous recent QTL mapping studies have begun to identify loci contributing to the "Sr2complex" resistance that has remained durable for over 50 years (Singh et al. 2013; Yu et al. 2011, 2012).

The Rpl locus of maize is composed of a family of NB-LRR genes that confer race-specific resistance to common rust ( $P$. sorghi) and some genes or gene combinations (haplotypes) show various phenotypic effects, including nonspecific resistance $(\mathrm{Hu}$ et al. 1996). The rpl genes mispair and recombine in meiosis, making recombinant genes and haplotypes that vary dramatically in gene numbers. Recombinant genes have been identified that respond to rust infection nonspecifically but also show spontaneous defense reactions, even without rust infection (Smith et al. 2010). Those with the strongest spontaneous HR destroy too much useful leaf area to be useful commercially. These extreme alleles, however, have been very useful tools for identifying naturally occurring allelic variants of genes controlling phenotypic variation in HR (Chaikam et al. 2011; Chintamanani et al. 2010; Olukolu et al. 2013) and identifying environmental conditions that affect Rpl-mediated responses. Other Rpl haplotypes have been identified that show partial resistance to common rust isolates that is unexpected from the individual genes they carry. For example, a recombinant haplotype carrying both $R p 1-D$ and $R p l-J$ showed partial resistance to isolates that neither gene confer resistance to and also provided partial resistance to southern rust (P. polysora) (Hu et al. 1997). The resistance was not noticeable in seedlings but became apparent once the plants had six to seven leaves. $R p l$ haplotypes providing this nonspecific resistance were also associated with spontaneous defense reactions. These were mainly confined to the lower leaves of adult plants in most maize lines but showed more severe effects in certain genetic backgrounds. 
Potential drawbacks with nonspecific resistance.

A common feature of nonspecific resistance loci identified to date is the occurrence of pleiotropic phenotypes, even in the absence of pathogen challenge (Fig. 1). Near-isogenic lines with Lr34 yielded approximately 5\% less than $\operatorname{lr} 34$ sibs in multiple field seasons in Mexico (Singh and Huerta-Espino 1997), presumably due to the physiological cost of reduced leaf area due to leaf tip necrosis in these genetic backgrounds and environments. Transformation of barley with Lr34 from wheat resulted in severe leaf tip necrosis throughout the plant life cycle and reduced vigor and seed production (Risk et al. 2013). Although selecting for $L r 34$ has undoubtedly been beneficial, it is not clear that the $\operatorname{lr} 34$ "yield" gene should be ignored in all breeding programs or production areas in the future. The glume pigmentation associated with $\mathrm{Sr} 2$ has also limited use of this gene historically, due to either negative effects on yield or breeder or farmer preference (Sheen et al. 1968; Singh et al. 2011). The CIMMYT Wheat Breeding program has continued to make impressive yield gains using combinations of Lr34, $\mathrm{Lr} 46, \mathrm{Sr} 2$, and other adult plant resistance loci extensively (Sharma et al. 2012; Singh et al. 2011) but it is unclear whether maintaining such resistance comes at a handicap. After 30 years of intensive breeding efforts at CIMMYT, other genes are undoubtedly being selected that limit such physiological effects; however, they are unknown and could limit application of the same resistance in other programs. Such modifiers and the "cost" of nonspecific resistance have been poorly studied, which will hopefully change in an era of perfect markers, inexpensive genotyping, increasingly employed genome-wide association studies, and integrated predictions of breeding value. From a practical breeding perspective, it will be a very longterm and challenging endeavor to increase the frequency of minor genes in entire breeding programs to the point that recovery of a high level of nonspecific resistance is routine in elite populations. At present, robust markers are only available for a limited number of nonspecific $R$ genes, and the population size required to fix even three genes in many elite backgrounds is impractical for many breeding programs in the short term. The same limitations of managing adequate population sizes while stacking genes exist for race-specific gene pyramids.

Another common feature of nonspecific resistance is the more obvious influence of maturity and environment on resistance expression. Temperature, humidity, and light intensity are regularly credited with altering their expression. Poor expression of Lr34 and Lr46 under higher temperatures has been noted (Lagudah 2011; Zhang et al. 2008). Their poor effective- ness in conditions when the environment is not appropriate has sometimes raised questions about whether they were effective against the prevailing rust races (Lagudah 2011). In contrast, Yr36 and many of the adult plant resistances used in the Pacific Northwest of the United States have poor expression in seasons when spring temperatures stay cool, and are commonly referred to as high-temperature adult plant resistances (Carter et al. 2009; Chen 2013; Lin and Chen 2007, 2009; Qayoum and Line 1985; Santra et al. 2008). In fact, chemical control of stripe rust is recommended on cultivars with relatively high levels of adult plant resistance in seasons with severe epidemic potential (Sharma-Poudyal and Chen 2011) (X. Chen, personal communication). Considering the epidemiology of rust diseases, expression of resistance only in later stages of development provides a mechanism for oversummering or overwintering and for more rapid increases in inoculum during early stages of epidemic development. Stripe rust races presently distributed throughout wheat-growing regions of the world have apparently become more aggressive under both cooler and warmer conditions (Milus et al. 2009), which could further complicate the use of $R$ genes with marked environmental sensitivity, especially in light of climate change predictions.

\section{Future prospects.}

Although both specific and nonspecific resistances have demonstrated their value in crop protection, neither has been employed optimally to date. Stewardship of effective $R$ genes is more feasible moving forward than ever before and traditional $R$ genes will have a role well into the future, as long as we continue to find or possibly create new specificities. Understanding effector function and distribution in pathogen populations and determining which effectors interact with $R$ genes with histories of effective use will inform selection of $R$ genes with more potential for durability. Characterization of genes with potentially nonspecific effects, including those mapped as QTL with relatively small but consistent effects, will reveal their function, which should shed light on how they can be combined for effective and durable resistance (Lowe et al. 2011). Additional work to determine their physiological costs, environmental dependencies, additive effects in combinations, and how easily rust fungi can adapt to their effects will help predict their value to breeding programs.

Transgenes are not currently used commercially to control diseases in cereals but this may change in the future. If a single transgene could control multiple rusts without a significant physiological cost, it could be a valuable tool to bolster breed-

Table 1. Overview of resistance in wheat to three rust diseases ${ }^{\mathrm{a}}$

\begin{tabular}{|c|c|c|c|}
\hline Category & Leaf rust & Stripe rust & Stem rust \\
\hline Resistance status & $\begin{array}{l}\text { Few broadly effective } R \text { genes are } \\
\text { available, and resistance in com- } \\
\text { mercial varieties is largely based on } \\
\text { combinations of regionally effective } \\
\text { or recycled or previously defeated } R \\
\text { genes and nonspecific resistance } \\
\text { loci }\end{array}$ & $\begin{array}{l}\text { Dozens of inadequately } \\
\text { characterized } R \text { genes and adult } \\
\text { plant resistance loci in commercial } \\
\text { varieties. } Y r 5 \text { and } Y r 15 \text { are being } \\
\text { used heavily around the globe in } \\
\text { breeding programs. Race-specific } \\
\text { adult plant resistance is common } \\
\text { but poorly characterized }\end{array}$ & $\begin{array}{l}\text { Most commercial varieties have } \\
\text { adequate resistance based on } R \\
\text { genes to local races but would be } \\
\text { susceptible to races in the Ug99 } \\
\text { lineage. } R \text { genes with broad } \\
\text { effectiveness include } S r 22, S r 26 \text {, } \\
\text { Sr32, Sr33, Sr39, } S r 40, S r 47, \text { and } \\
\text { Sr50; many other genes confer } \\
\text { resistance to Ug99-races, which } \\
\text { could be combined with existing } \\
\text { genes effective against local races }\end{array}$ \\
\hline $\begin{array}{l}\text { Potentially nonspecific resistance } \\
\text { sources identified }\end{array}$ & $\begin{array}{l}\text { Lr34 (Yr18/Sr57), Lr46 (Yr29/Sr58), } \\
\text { Lr67 (Yr46/Sr55), Lr68, and several } \\
\text { inadequately characterized loci }\end{array}$ & $\begin{array}{l}\operatorname{Lr} 34, \operatorname{Lr} 46, \operatorname{Yr} 30(\mathrm{Sr} 2), \operatorname{Lr} 67 \text {, and } \\
\text { numerous adult plant resistance } \\
\text { loci, some of which have been well } \\
\text { characterized, such as } \operatorname{Yr} 36 \text { and } \\
\text { Yr48, and many that have been } \\
\text { inadequately characterized }\end{array}$ & $\begin{array}{l}\operatorname{Sr} 2, \operatorname{Lr} 34, \operatorname{Lr} 46, \operatorname{Lr} 67, \operatorname{Sr} 56, \text { and } \\
\text { numerous inadequately } \\
\text { characterized loci }\end{array}$ \\
\hline Relative global losses in recent years & Moderate & High & Low \\
\hline
\end{tabular}

${ }^{\mathrm{a}} R=$ resistance gene. 
ing efforts. The observation that Puccinia genes can be silenced in haustorial cells by RNAi expression in wheat plants and that this can affect pathogenicity (Panwar et al. 2013a and b) has exciting implications. Genes that are conserved across Puccinia spp. and important to pathogenicity could be valuable targets for engineering resistance to multiple rust species. Simultaneously silencing several important genes could, in theory, provide durable resistance unless mutations that disarm rust fungus gene-silencing systems can occur without deleterious effects. Genes encoding protein effectors may not be the best targets for engineering durable resistance, especially when trying to control multiple rust species, because they typically appear to be less conserved between species (Duplessis et al. 2011). Because intracellular recognition of proteins is not necessary for this type of suppression to occur, genes involved in basic pathogenicity or more essential cellular processes in haustorial cells may be better targets. The genes examined by Panwar et al. (2013b) were sufficiently conserved to silence homologs in multiple rust species. Another possible target could be the IaaM genes that Puccinia spp. use to cause wheat to overproduce auxin in infected tissue (Yin et al. 2014). The gene is conserved across all three wheat rust fungi and transient silencing in $P$. graminis indicated that it was essential for full pathogenicity.

In the shorter term, development of cereal varieties with durable resistance is dependent on germplasm development. Transferring multiple genes, whether specific or nonspecific, to elite genetic backgrounds is an often overlooked and unfashionable necessity at the cornerstone of durable resistance. Straightforward germplasm development approaches exist but all are resource intensive, even if diagnostic markers are available with inexpensive genotyping, doubled haploid programs, and improved selection methods. Simply stated, germplasm development is perhaps the greatest limitation to realizing durable cereal rust resistance and responsible gene stewardship, even with tremendous existing and emerging resources (Table 1). One good race-specific gene in an elite cultivar is worth three in the bush to most plant breeders. If durable resistance is a desired outcome, not just a desirable idea, future efforts must increase emphasis on delivering regionally adapted germplasm that enables deployment of durable resistance.

\section{ACKNOWLEDGMENTS}

We acknowledge financial resources from the Durable Rust Resistant Wheat Project led by Cornell University, United States Department of Agriculture National Institute of Food and Agriculture projects 201168002-30029 and 2012-67013-19400, and the Washington Grain Commission PPNS no. 0641, College of Agricultural, Human, and Natural Resource Sciences, Agricultural Research Center, Hatch Project no. WNP00663, Washington State University, Pullman, WA, U.S.A. We thank X. Chen, A. Kleinhofs, J. Nirmala, C. Yin, and R. Bowden.

\section{LITERATURE CITED}

Anderson, P. A., Lawrence, G. J., Morrish, B. C., Ayliffe, M. A., Finnegan, E. J., and Ellis, J. G. 1997. Inactivation of the flax rust resistance gene $\mathrm{M}$ associated with loss of a repeated unit within the leucine-rich repeat coding region. Plant Cell 9:641-651.

Ayliffe, M., Singh, R., and Lagudah, E. 2008. Durable resistance to wheat stem rust needed. Curr. Opin. Plant Biol. 11:187-192.

Carter, A. H., Chen, X. M., Garland-Campbell, K., and Kidwell K. K. 2009. Identifying QTL for high-temperature adult-plant resistance to stripe rust (Puccinia striiformis f. sp. tritici) in the spring wheat (Triticum aestivum L.) cultivar 'Louise'. Theor. Appl. Genet. 119:1119-1128.

Catanzariti, A.-M., Dodds, P. N., Lawrence, G. J., Ayliffe, M. A., and Ellis, J. G. 2006. Haustorially expressed secreted proteins from flax rust are highly enriched for avirulence elicitors. Plant Cell 18:243-256.

Chaikam, V., Negeri, A., Dhawan, R., Puchaka, B., Ji, J., Chintamanani, S., Gachomo, E. W., Zillmer, A., Doran, T., Weil, C., Balint-Kurti, P., and Johal, G. 2011. Use of mutant-assisted gene identification and characterization (MAGIC) to identify novel genetic loci that modify the maize hypersensitive response. Theor. Appl. Genet. 123:985-997.

Chen, X. 2013. Review article: High-temperature adult-plant resistance, key for sustainable control of stripe rust. Am. J. Plant Sci. 4:608-627.

Chintamanani, S., Hulbert, S. H., Johal, G. S., and Balint-Kurti, P. J. 2010. Identification of a maize locus that modulates the hypersensitive defense response using mutant-assisted gene identification and characterization. Genetics 184:813-825.

Collins, N., Drake, J., Ayliffe, M., Sun, Q., Ellis, J., Hulbert, S., and Pryor, T. 1999. Molecular characterization of the maize Rp1-D rust resistance haplotype and its mutants. Plant Cell 11:1365-1376.

Cloutier, S., McCallum, B. D., Loutre, C., Banks, T. W., Wicker, T., Feuillet, C., Keller, B., and Jordan, M. C. 2007. Leaf rust resistance gene Lr1, isolated from bread wheat (Triticum aestivum L.) is a member of the large psr567 gene family. Plant Mol. Biol. 65:93-106.

Collins, N., Drake, J., Ayliffe, M., Sun, Q., Ellis, J., Hulbert, S., and Pryor, T. 1999. Molecular characterization of the maize $R p 1-D$ rust resistance haplotype and its mutants. Plant Cell 11:1365-1376.

de Jonge, R., van Esse, H. P., Kombrink, A., Shinya, T., Desaki, Y., Bours, R., van der Krol, S., Shibuya, N., Joosten, M. H. A. J., and Thomma, B. P. H. J. 2010. Conserved fungal LysM effector Ecp6 prevents chitintriggered immunity in plants. Science 329:953-955.

Dodds, P. N., and Rathjen, J. P. 2010. Plant immunity: Towards an integrated view of plant-pathogen interactions. Nat. Rev. Genet. 11:539548.

Dodds, P. N., Lawrence, G. J. and, Ellis, J. G. 2001a. Contrasting modes of evolution acting on the complex $N$ locus for rust resistance in flax. Plant J. 27:439-453.

Dodds, P. N., Lawrence, G. J., Pryor, T., and Ellis, J. G. 2001b. Six amino acid changes confined to the leucine-rich repeat b-strand/b-turn motif determine the difference between the $P$ and $P 2$ rust resistance specificities in flax. Plant Cell 13:163-178.

Dodds, P. N., Lawrence, G. J., Catanzariti, A., Ayliffe, M. A., and Ellis, J. G. 2004. The Melampsora lini AvrL567 avirulence genes are expressed in haustoria and their products are recognized inside plant cells. Plant Cell 16:755-768.

Dodds, P. N., Lawrence, G. J., Catanzariti, A.-M., Teh, T., Wang, C.-I. A., Ayliffe, M. A., Kobe, B., and Ellis, J. G. 2006. Direct protein interaction underlies gene-for-gene specificity and coevolution of the flax resistance genes and flax rust avirulence genes. Proc. Natl. Acad. Sci. U.S.A. 103:8888-8893.

Duplessis, S., Cuomo, C. A., Lin, Y.-C., Aerts, A., Tisserant, E., VeneaultFourrey, C., Joly, D. L., Hacquard, S., Amselem, J., Cantarel, B. L., Chiu, R., Coutinho, P. M., Feau, N., Field, M., Frey, P., Gelhaye, E., Goldberg, J., Grabherr, M. G., Kodira, C. D., Kohler, A., Kües, U., Lindquist, E. A., Lucas, S. M., Mago, R., Mauceli, E., Morin, E., Murat, C., Pangilinan, J. L., Park, R., Pearson, M., Quesneville, H., Rouhier, N., Sakthikumar, S., Salamov, A. A., Schmutz, J., Selles, B., Shapiro, H., Tanguay, P., Tuskan, G. A., Henrissat, B., Van de Peer, Y., Rouzé, P., Ellis, J. G., Dodds, P. N., Schein, J. E., Zhong, S., Hamelin, R. C., Grigoriev, I. V., Szabo, L. J., and Martin, F. 2011. Obligate biotrophy features unraveled by the genomic analysis of rust fungi. Proc. Natl. Acad. Sci. U.S.A. 108:9166-9171.

Faris, J. D., Zhang, Z., Lu, H., Lu, S., Reddy, L., Cloutier, S., Fellers, J. P. Meinhardt, S. W., Rasmussen, J. B., Xu, S. S., Oliver, R. P., Simons, K. J., and Friesen, T. L. 2010. A unique wheat disease resistance-like gene governs effector-triggered susceptibility to necrotrophic pathogens. Proc. Natl. Acad. Sci. U.S.A. 107:13544-13549.

Feuillet, C., Travella, S., Stein, N., Albar, L., Nublat, A., and Keller, B. 2003. Map-based isolation of the leaf rust disease resistance gene $\mathrm{Lr} 10$ from the hexaploid wheat (Triticum aestivum L.) genome. Proc. Natl. Acad. Sci. U.S.A. 100:15253-15258.

Fu, D. L., Uauy, C., Distelfeld, A., Blechl, A., Epstein, L., Chen, X. M., Sela, H. A., Fahima, T., and Dubcovsky, J. 2009. A kinase-START gene confers temperature-dependent resistance to wheat stripe rust. Science 323:1357-1360.

Garnica, D. P., Upadhyaya, N. M., Dodds, P. N., and Rathjen, J. P. 2013. Strategies for wheat stripe rust pathogenicity identified by transcriptome sequencing. PLoS One 26:e67150. Published online.

German, S. E., and Kolmer, J. A. 1992. Effect of gene Lr34 in the enhancement of resistance to leaf rust of wheat. Theor. Appl. Genet. 84:97-105.

Herrera-Foessel, S. A., Lagudah, E. S., Huerta-Espino, J., Hayden, M. J., Bariana, H. S., Sing, D., and Sing, R. P. 2011. New slow-rusting leaf rust and stripe rust resistance genes Lr67 and Yr46 in wheat are pleiotropic or closely linked. Theor. Appl. Genet. 122:239-249.

Hiebert, C. W., Thomas, J. B., McCallum, B. D., Humphreys, D. G., DePauw, R. M., Hayden, M. J., Mago, R., Schnippenkoetter, W., and Spielmeyer, W. 2010. An introgression on wheat chromosome 4DL in 
RL6077 (Thatcher*6/PI250413) confers adult plant resistance to stripe rust and leaf rust (Lr67).Theor. Appl. Genet. 121:1083-1091.

Hogenhout, S. A., Van der Hoorn, R. A. L., Terauchi, R., and Kamoun, S 2009. Emerging concepts in effector biology of plant-associated organisms. Mol. Plant Microbe Interact. 22:115-122.

Hu, G., Richter, T. E. Hulbert, S. H., and Pryor, A. J. 1996. Disease lesion mimicry caused by mutations at the rust resistance gene Rp1. Plant Cell 8:1367-1376.

Hu, G., Webb, C. A., and Hulbert, S. H. 1997. Adult-plant phenotype of the Rp1-DJ compound rust resistance gene in maize. Phytopathology 87:236-241.

Huang, L., Brooks, S. A., Li, W., Fellers, J. P., Trick, H. N., and Gill, B. S 2003. Map-based cloning of leaf rust resistance gene Lr21 from the large and polyploid genome of bread wheat. Genetics 164:655-664.

Hulbert, S. H., Bai, J., Fellers, J. P., Pacheco, M. G., and Bowden, R. L. 2007. Gene expression patterns in near isogenic lines for wheat rust resistance gene Lr34/Yr18. Phytopathology 97:1083-1093.

Johnson R. 1978. Practical breeding for durable resistance to rust diseases in self-pollinating cereals. Euphytica 27:529-540.

Jones, J. D. G., and Dangl, J. L. 2006. The plant immune system. Nature 444:323-329.

Kleinhofs, A., Brueggeman, R., Nirmala, J., Zhang, L., Mirlohi, A., Druka, A., Rostoks, N., and Steffenson, B. J. 2009. Barley stem rust resistance genes: Structure and function. Plant Genome J. 2:109.

Kota, R., Spielmeyer, W., McIntosh, R. A., and Lagudah, E. S. 2006. Fine genetic mapping fails to dissociate durable stem rust resistance gene Sr2 from pseudo-black chaff in common wheat (Triticum aestivum L.) Theor. Appl. Genet. 112:492-499.

Krattinger, S. G., Lagudah, E. S., Spielmeyer, W., Singh, R. P., HuertaEspino, J., McFadden, H., Bossolini, E., Selter, L. L., and Keller, B. 2009. A putative $\mathrm{ABC}$ transporter confers durable resistance to multiple fungal pathogens in wheat. Science 323:1360-1363.

Lagudah, E. S. 2011. Molecular genetics of race non-specific rust resistance in wheat. Euphytica 179:81-91.

Lawrence, G. J., Finnegan, E. J., Ayliffe, M. A., and Ellis, J. G. 1995. The L6 gene for flax rust resistance is related to the Arabidopsis bacterial resistance gene Rps2 and the tobacco viral resistance gene N. Plant Cell 7:1195-1206.

Leach, J. E., Vera Cruz, C. M., Bai, J., and Leung, H. 2001. Pathogen fitness penalty as a predictor of durability of disease resistance genes. Annu. Rev. Phytopathol. 39:187-224.

Lillemo, M., Joshi, A. K., Prasad, R., Chand, R., and Singh, R. P. 2013. QTL for spot blotch resistance in bread wheat line Saar co-locate to the biotrophic disease resistance loci Lr34 and Lr46. Theor. Appl. Genet. 126:711-719.

Lin, F., and Chen, X. M. 2007. Genetics and molecular mapping of genes for race-specific all-stage resistance and non-race-specific high-temperature adult-plant resistance to stripe rust in spring wheat cultivar Alpowa. Theor. Appl. Genet. 114:1277-1287.

Lin, F., and Chen, X. M. 2009. Quantitative trait loci for non-race-specific, high-temperature adult-plant resistance to stripe rust in wheat cultivar Express. Theor. Appl. Genet. 118:631-642.

Loutre, C., Wicker, T., Travella, S., Galli, P., Scofield, S., Fahima, T., Feuillet, C. and Keller, B. 2009. Two different CC-NBS-LRR genes are required for $\mathrm{Lr} 10$-mediated leaf rust resistance in tetraploid and hexaploid wheat. Plant J. 60:1043-1054

Lowe, I., Cantu, D., and Dubcovscy, J. 2011. Durable resistance to the wheat rusts: Integrating systems biology and traditional phenotypebased research methods to guide the deployment of resistance genes. Euphytica 179:69-79.

Mago, R., Tabe, L., McIntosh, R. A., Pretorius, Z., Kota, R., Paux, E., Wicker, T., Breen, J., Lagudah, E. S., Ellis, J. G., and Spielmeyer, W. 2011. A multiple resistance locus on chromosome arm 3BS in wheat confers resistance to stem rust $(\mathrm{Sr} 2)$, leaf rust $(\mathrm{Lr} 27)$ and powdery mildew. Theor. Appl. Genet. 123:615-623.

McIntosh, R. A., Wellings, C. R., and Park, R. F. 1995. Wheat Rusts: An Atlas of Resistance Genes. CSIRO Publications, East Melbourne, Australia.

Milus, E. A., Kristensen, K., and Hovmøller, M. S. 2009. Evidence for increased aggressiveness in a recent widespread strain of Puccinia striiformis f. sp. tritici causing stripe rust of wheat. Phytopathology 99:8994.

Nirmala, J., Drader, T., Chen, X., Steffenson, B., and Kleinhofs, A. 2010. Stem rust spores elicit rapid RPG1 phosphorylation. Mol. PlantMicrobe Interact. 23:1635-1642.

Nirmala, J., Drader, T., Lawrence, P. K., Yin, C., Hulbert, S., Steber, C. M., Steffensone, B. J., Szabof, L. J., von Wettsteina, D., and Kleinhofs, A. 2011. Concerted action of two avirulent spore effectors activates reaction to Puccinia graminis 1 (Rpg1)-mediated cereal stem rust resistance. Proc. Natl. Acad. Sci. U.S.A. 108:14676-14681.
Olson, E. L., Rouse, M., Pumphrey, M., Bowden, R., Gill, B. S., and Poland, J. 2013. Introgression of stem rust resistance genes SrTA10187 and SrTA10171 from Aegilops tauschii to wheat. Theor. Appl. Genet. 126:2477-2484.

Olukolu, B. A., Negeri, A., Dhawan, R., Venkata, B. P., Sharma, P., Garg, A., Gachomo, E., Marla, S., Chu, K., Hasan, A., Ji, J., Chintamanani, S., Green, J., Shyu, C.-R., Wisser, R., Holland, J., Johal, G., and BalintKurti, P. 2013. A connected set of genes associated with programmed cell death implicated in controlling the hypersensitive response in maize. Genetics 193:609-620.

Panwar, V., McCallum, B., and Bakkeren, G. 2013a. Host-induced gene silencing of wheat leaf rust fungus Puccinia triticina pathogenicity genes mediated by the Barley stripe mosaic virus. Plant Mol. Biol. 81:595-608.

Panwar, V., McCallum, B., and Bakkeren, G. 2013b. Endogenous silencing of Puccinia triticina pathogenicity genes through in planta-expressed sequences leads to the suppression of rust diseases on wheat. Plant $\mathbf{J}$ 73:521-532.

Pardey, P. G., Beddow, J. M., Kriticos, D. J., Hurley, T. M., Park, R. F., Duveiller, E., Sutherst, R. W., Burdon, J. J., and Hodson, D. 2013. Right-sizing stem-rust research. Science 340:147-148.

Parlevliet, J. E. 1985. Resistance of the non-race-specific type. Pages 501525 in: The Cereal Rusts, Vol. II. A. P. Roelfs and W. R. Bushnell, eds. Academic Press, Orlando, FL, U.S.A.

Periyannan, S., Moore, J., Ayliffe, M., Bansal, U., Wang, X., Huang, L., Deal, K., Luo, M., Kong, X., Bariana, H., Mago, R., McIntosh, R., Dodds, P., Dvorak, J., and Lagudah, E. 2013. The gene Sr33, an ortholog of barley Mla genes, encodes resistance to wheat stem rust race Ug99. Science 341:786-788.

Pumphrey, M. O. 2012. Stocking the breeder's toolbox: An update on the status of resistance to stem rust in wheat. Pages 23-29 in: Proceedings Borlaug Global Rust Initiative 2012 Technical Workshop. R. McIntosh, ed. Beijing, China.

Qayoum, A., and Line, R. F. 1985. High-temperature, adult-plant resistance to stripe rust of wheat. Phytopathology 75:1121-1125.

Qi, X., Jiang, G., Chen, W., Niks, R. E., Stam, P., and Lindhout, P. 1999. Isolate-specific QTLs for partial resistance to Puccinia hordei in barley. Theor. Appl. Genet. 99:877-884.

Ravensdale, M., Bernoux, M., Ve, T., Kobe, B., Thrall, P. H., Ellis, J. G., and Dodds, P. N. 2012. Intramolecular interaction influences binding of the Flax L5 and L6 resistance proteins to their AvrL567 ligands. PLoS Pathog. 8:e1003004. Published online.

Risk, J. M., Selter, L. L., Chauhan, H., Krattinger, S. G., Kumlehn, J. Hensel, G., Viccars, L. A., Richardson, T. M., Buesing, G., Troller, A., Lagudah, E. S., and Keller, B. 2013. The wheat Lr34 gene provides resistance against multiple fungal pathogens in barley. Plant Biotechnol. J. 11:847-854.

Saintenac, C., Zhang, W., Salcedo, A., Rouse, M. N., Trick, H. N., Akhunov, E., and Dubcovsky, J. 2013. Identification of wheat gene Sr35 that confers resistance to Ug99 stem rust race group. Science 341:783786.

Santra, D. K., Chen, X. M., Santra, M., Campbell, K. G., and Kidwell, K. K. 2008. Identification and mapping QTL for high-temperature adultplant resistance to stripe rust in winter wheat (Triticum aestivum L.) cultivar 'Stephens'. Theor. Appl. Genet. 117:793-802.

Sharma, R. C., Crossa, J., Velu, G., Huerta-Espino, J., Vargas, M., Payne, T. S., and Singh R. P. 2012. Genetic gains for grain yield in CIMMYT spring bread wheat across international environments. Crop Sci. 52:1522-1533

Sharma-Poudyal, D., and Chen, X. M. 2011. Models for predicting potential yield loss of wheat caused by stripe rust in the U.S. Pacific Northwest. Phytopathology 101:544-554.

Sheen, S.-J., Ebeltoft, D. C., and Smith, G. S. 1968. Association and inheritance of "black chaff" and stem rust reactions in Conley wheat crosses. Crop Sci. 8:477-480.

Singh, A., Knox, R. E., DePauw, R. M., Singh, A. K., Cuthbert, R. D., Campbell, H. L., Singh, D., Bhavani, S., Fetch, T., and Clarke, F. 2013. Identification and mapping in spring wheat of genetic factors controlling stem rust resistance and the study of their epistatic interactions across multiple environments. Theor. Appl. Genet. 126:1951-1964.

Singh, R. P., and Huerta-Espino, J. 1997. Effect of leaf rust resistance gene Lr34 on grain yield and agronomic traits of spring wheat. Crop Sci. 37:390-395.

Singh, R. P., and Huerta-Espino, J. 2003. Effects of leaf rust resistance gene Lr34 on components of slow rusting at seven growth stages in wheat. Euphytica 129:371-376.

Singh, R. P., Mujeeb-Kazi, A., and Huerta-Espino, J. 1998. Lr46: A gene conferring slow-rusting resistance to leaf rust in wheat. J. Phytopathol. 88:890-894

Singh, R. P., Huerta-Espino, J., Bhavani, S., Herrera-Foessel, S. A., Singh, 
D., Singh, P. K., Velu, G., Mason, R. E., Jin, Y., Njau, P., and Crossa, J. 2011. Race non-specific resistance to rust diseases in CIMMYT spring wheats. Euphytica 179:175-186.

Singh, S., and Bowden, R. L. 2011. Molecular mapping of adult-plant race-specific leaf rust resistance gene Lr12 in bread wheat. Mol. Breed. 28:137-142.

Singh, S., Singh R. P., Bhavani, S., Huerta-Espino, J., and Eugenio, L. V. 2013. QTL mapping of slow-rusting, adult plant resistance to race Ug99 of stem rust fungus in PBW343/Muu RIL population. Theor. Appl. Genet. 126:1367-1375.

Smith, S. M., Steinau, M., Trick, H. N., and Hulbert, S. H. 2010 Recombinant Rpl genes confer necrotic or nonspecific resistance phenotypes. Mol. Genet. Genomics 283:591-602.

Spielmeyer, W., Mago, R., Wellings, C., and Ayliffe, M. 2013. Lr67 and Lr34 rust resistance genes have much in common-they confer broad spectrum resistance to multiple pathogens in wheat. BMC Plant Biol. 13:96.

Steffenson, B. J. 1992. Analysis of durable resistance to stem rust in barley. Euphytica 63:153-167.

Sthapit, J., Gbur, E. E., Brown-Guedira, G., Marshall, D. S., and Milus, E. A. 2012. Characterization of resistance to stripe rust in contemporary cultivars and lines of winter wheat from the eastern United States. Plant Dis. 96:737-745.

Sun, Q., Collins, N., Ayliffe, M., Smith, S., Drake, J., Pryor, T., and Hulbert, S. 2001. Recombination between paralogues at the $r p 1$ rust resistance locus in maize. Genetics 158:423-438.

Thomma, B. P. H. J., Nürnberger, T., and Joosten, M. H. A. J. 2011. Of PAMPs and effectors: The blurred PTI-ETI dichotomy. Plant Cell 23:415.

Tian, M., Chaudhry, F., Ruzicka, D. R., Meagher, R. B., Staiger, C. J., and Day, B. 2009. Arabidopsis actin-depolymerizing factor AtADF4 mediates defense signal transduction triggered by the Pseudomonas syringae effector AvrPphB. Plant Physiol. 150:815-824.

Upadhyaya, N. M., Mago, R., Staskawicz, B. J., Ayliffe, M. A., Ellis, J. G., and Dodds, P. N. 2014. A bacterial type III secretion assay for delivery of fungal effector proteins into wheat. Mol. Plant-Microbe Interact. 27:255-264.

Wang, X., Richards, J., Gross, T., Druka, A., Kleinhofs, A., Steffenson, B. Acevedo, M., and Brueggeman, R. 2013. The rpg4-mediated resistance to wheat stem rust (Puccinia graminis) in barley (Hordeum vulgare) requires Rpg5, a second NBS-LRR gene, and an actin depolymerization factor. Mol. Plant-Microbe interact. 26:407-418.

Webb, C. A., Richter, T. E., Collins, N. C., Nicolas, M., Trick, H. N., Pryor, T., and Hulbert, S. H. 2002. Genetic and molecular characterization of the maize Rp3 rust resistance locus. Genetics 162:381-394.

Wesp-Guterres, C., Martinelli, J. A., Graichen, F. A. S., and Chaves, M. S. 2013. Histopathology of durable adult plant resistance to leaf rust in the Brazilian wheat variety Toropi. Eur. J. Plant Pathol. 137:181-196.

Yin, C., and Hulbert, S. 2011. Prospects for functional analysis of effectors from cereal rust fungi. Euphytica 179:57-67.

Yin, C., Jurgenson, J. E., and Hulbert, S. 2011. Development of a hostinduced RNAi system in the wheat stripe rust fungus Puccinia striiformis f. sp. tritici. Mol. Plant-Microbe Interact. 24:554-561.

Yin, C., Park, J.-J., Gang, D. R., and Hulbert, S. H. 2014. Characterization of a tryptophan 2-monooxygenase gene from Puccinia graminis $\mathrm{f}$. $\mathrm{sp}$ tritici involved in auxin biosynthesis and rust pathogenicity. Mol. PlantMicrobe Interact. 27:227-235.

Yu, L. X., Lorenz, A., Rutkoski, J., Singh, R. P., Bhavani, S., HuertaEspino, J., and Sorrells, M. E. 2011. Association mapping and genegene interaction for stem rust resistance in CIMMYT spring wheat germplasm. Theor. Appl. Genet. 123:1257-1268.

Yu, L. X., Morgounov, A., Wanyera, R., Keser, M., Singh, S. K., and Sorrells M. 2012. Identification of Ug99 stem rust resistance loci in winter wheat germplasm using genome-wide association analysis. Theor. Appl. Genet. 125:749-758.

Zhang, J. X., Singh, R. P., Kolmer, J. A., Huerta-Espino, J., Jin, Y., and Anderson, J. A. 2008. Inheritance of leaf rust resistance in CIMMYT wheat Weebill 1. Crop Sci. 48:1037-1047. 